https://doi.org/10.52240/1857-2367.2020.2(21).36

\title{
COLECT,IA GENULUI CLEMATIS L. ÎN GRĂDINA BOTANICĂ NAȚIONALĂ (INSTITUT) „ALEXANDRU CIUBOTARU”
}

\author{
Vasile BEȘELEA \\ Grădina Botanică Națională (Institut) "Al. Ciubotaru”, \\ Chișinău, Republica Moldova
}

\begin{abstract}
The paper gives the characteristic of the collection of Clematis L. in the"Alexandru Ciubotaru" National Botanical Garden (Institute)
\end{abstract}

Key words: Clematis L., flowers, collection, Republic of Moldova.

Genul Clematis L.(Curpen) al familiei Ranunculaceae Juss. însumează cca 370 de specii [3] și sute de cultivaruri, răspândite în zonele temperate ale Emisferei de Nord. În flora Republicii Moldova vegetează spontan 3 specii de Clematis: C. vitalba L., C. integrifolia L. și C. recta L. [1]. Specia C. integrifolia L., este indicată ca fiind plantă rară [2].

Speciile genului Clematis L. sunt plante valoroase pentru amenajarea spațiilor verzi, insă insuficient studiate în condițiile țării noastre. Posedă indici de decorativitate deosebiți și o diversitate foarte largă de culori, forme și dimensiuni. Unele specii și cultivaruri posedă flori aromate și fructe decorative. Majoritatea taxonilor din genul Clematis L. conțin substanţe tanante, fitoncide, uleiuri aromatice, vitamina C și sunt melifere (Danilenco, Rodionov, 1981). Actualmente în amenajarea spațiilor rurale și urbane ale țării reprezentanții genului, practic, nu sunt utilizați, deși popularitatea și solicitarea lor este în continuă creștere.

În Republica Moldova cea mai mare parte din materialul săditor este importat din Europa. În cadrul Grădinii Botanice (anul 2018) a fost restabilită expoziția de liane (Lianarium), fiind completată și colecția genului Clematis (35 de cultivaruri) ca urmare a implimentării proiectului „Restabilirea ecologică a expoziției de lianariu din Gradina Botanică Națională (I) „Al. Ciubotaru”, finanțat de Oficiul de Dezvoltare și Cooperare Austriac. 
Cultivarurile noi introduse pot fi încadrate în mai multe grupe horticole [4]:

1. Grupul Early Large Flowered. Acest grup de plante se caracterizează prin muguri mari, în poziție verticală. Florile sunt printre cele mai mari pe care le putem vedea la soiurile din genul Clematis, având în diametru $15-25 \mathrm{~cm}$, în formă de stea, pot fi simple, semi-duble sau duble și sunt disponibile într-o gamă largă de culori. Perioada de înflorire durează de la sfârșitul primaverii pâna spre sfârșitul verii. În cadrul colecției din Grădina Botanică se întâlnesc cultivarurile: 'Andromeda', 'Beautiful Bride PBR', 'Blue Explosion PBR', 'Isago' etc.

2. Grupul Viorna. Clematitele din acest grup sunt plante cu frunze penate, pețiolate, cu petale simple sau triple. Florile se formează pe lăstarii anului curent, de la sfârșitul primăverii până la începutul toamnei. Au o înflorire axilară sau terminală. Florile sunt în formă de cupă sau clopoțel, având un diametru de 1,5-5 cm. Culorile predominante - alb, galben, violet, roz. Ca reprezentant în colecție este cultivarul 'Princess Red'.

3. Grupul Integrifolia. Sunt liane asemănătoare unui arbust. Florile se formează pe lăstarii anului curent vara și toamna devreme, în formă de clopoțel și având diametrul de 4-9 cm. Perioada de înflorire este iulie-octombrie. Nuanțele predominante: alb, roz, roșu, albastru. Cultivarurile prezente în colecție: 'Alionushka', 'Arabella'.

4. Grupul Viticella. Acest grup include soiuri cu florile ce se formează pe lastarii anului curent vara și toamna devreme, în special, lunile iunie și august, au diametrul de 2,5-5 cm. Este o liană asemănătoare unui arbore cu o înălțime de 2-4 m. Frunzele au formă ovală cu diametru de $1,5-5 \mathrm{~cm}$ și vârfurile ascuțite. Nuanțele predominante: monocromatice, albe și diverse nuanțe de roz. Reprezentanții: 'Etoile Violette', 'Justa', 'Purpurea Plena Eleg'.

5. Grupul Latte large Flowered. Reprezentanții acestui grup sunt plante cu flori simple sau duble sub formă de clopoțel, atingând $5-12 \mathrm{~cm}$ în diametru. Perioada de înflorire a exemplarelor acestui grup cuprinde lunile mai și iunie. Multe din aceste clematite timpurii, cu flori mari, au nuanțe florale care variază de la alb și albastru-lavandă la un albastru bogat, roz și roșii. Soiuri prezente în colecție: 'Dănuta', 'Jackmanii', 'Polish Spirit', 'Morning Sky'.

Pe măsura completării colecției, se lărgeşte spectrul cercetărilor ştiinţifice, se întreprind investigaţii biomorfologice şi ecologice ale speciilor şi cultivarurilor în condiţii ex-situ, pentru elaborarea tehnologiilor de cultivare, a sortimentului pentru amenajarea spațiilor verzi, conservarea taxonilor rari şi evidenţierea celor de perspectivă pentru economia naţională.

Cercetările s-au efectuat și continuă în cadrul proiectului: 20.80009.7007.19 „Introducerea și elaborarea tehnologiilor de multiplicare și cultivare prin tehnici convenționale și culturi in vitro a speciilor de plante lemnoase noi”.

\section{BIBLIOGRAFIE}

1. Negru A. Determinator de plante din flora Republicii Moldova. Chişinău, 2007, 391 p.

2. Negru A. ş. a. Plantele rare din flora spontană a R. Moldova. Chişinău, 2002, 198 p.

3. http:// www.theplantlist.org/ (vizitat 28.10.2020)

4. http://clematisinternational.com/. 